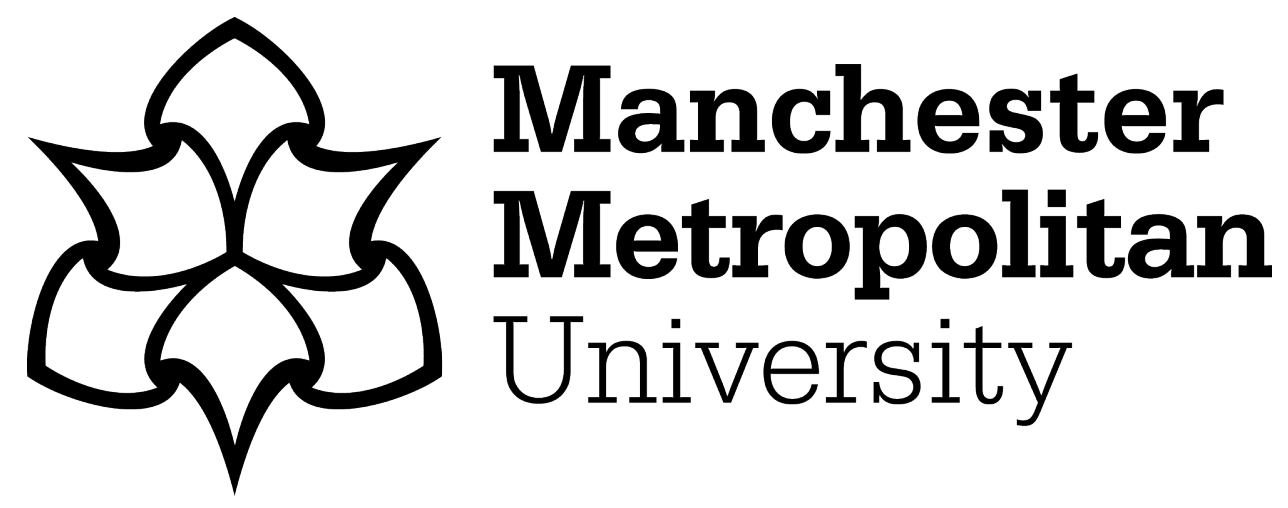

Alexis-Martin, Becky (2019) The nuclear imperialism-necropolitics nexus: contextualizing Chinese-Uyghur oppression in our nuclear age. Eurasian Geography and Economics, 60 (2). pp. 152-176. ISSN 1538-7216

Downloaded from: https://e-space.mmu.ac.uk/623657/

Version: Accepted Version

Publisher: Informa UK Limited

DOI: https://doi.org/10.1080/15387216.2019.1645611

Please cite the published version 


\title{
The nuclear imperialism-necropolitics nexus: contextualizing Chinese-Uyghur oppression in our nuclear age
}

\author{
Becky Alexis-Martin
}

Geography and Environment, Manchester Metropolitan University, Manchester, UK

\begin{abstract}
This paper provides a review of the People's Republic of China's (PRC) nuclear warfare development and uranium mining programs in the Xinjiang Uyghur Autonomous Region. Its scope spans from PRC's first nuclear weapon test in Lop Nur during the early Cold War, to the contemporary issues surrounding in-situ leach uranium mining in the Yili basin which now provides a third of PRC's uranium. By exploring these scenarios, it is possible to place a lens on the parameters and limitations to indigenous Uyghur life within a nuclear state. This paper draws on the work of Achille Mbembe's necropolitics, whereby power is persistently exercised as violence, to consider the entangled aftermath of nuclear imperialism and its harmful consequences to Uyghur bodies, environment and culture. While racialized nuclear imperialism presented Uyghur lives as inconsequential to industrial and military progress in Xinjiang, post-Cold War necropolitics presents Uyghur culture as a direct threat to the progress and values of the PRC sovereign state. This paper proposes that the ongoing exploitation of nuclear Xinjiang provides an additional motivation for state-imposed necropolitical sanctions upon Uyghur people. This paper also presents a new theoretical contribution, the "nuclear imperialismnecropolitics nexus", which offers a way to consider the legacy of injustice of spaces of nuclear activity, from nuclear imperialism to the post-Cold War world.
\end{abstract}

\section{Introduction}

This paper expands upon existing understandings of injustices perpetuated by the sovereign state in Xinjiang Uyghur Autonomous Region, the People's Republic of China (PRC); to encompass notions of nuclear imperialism and necropolitics, which have been drawn together to present a "nuclear imperialism-necropolitics nexus". I argue that the colonization of Uyghur lands and their use by the PRC for nuclear weapon testing are representative of a mode of nuclear imperialism that treated Uyghur life as worthless. However, this 
older form of power has since been folded into a new form of necropolitics, whereby Uyghur life has become all too consequential. Uyghur people and their traditional way of life have now become the target of destruction. While retaining nuclear weapon possessor status, the PRC is now in the midst of a nuclear energy renaissance and currently has the world's largest nuclear energy development program. Commercial nuclear energy was not a priority for the PRC until 2005, due to a lack of political and economic incentives during the Cold War, and an abundance of other national energy sources including coal-fired power stations and hydroelectric power (Zhou et al. 2011). This means that spaces of injustice that were originally associated with nuclear-weapons testing are now being reasserted for energy rather than warfare, with repercussions to Uyghur.

Research has been undertaken to examine how nuclear technologies interact across a spectrum of geographic scales, encompassing zones, communitiesand bodies (Alexis-Martin and Davies 2017; Pitkanen and Farish 2018). This field has been described as nuclear geography, and its key concerns are the benefits and challenges that emerge as humans coexist with spaces of nuclear phenomena including warfare, energy and medicine. Prior work notes that nuclear technology changes the nature of power's relationship to geographical space, as militarization or industrialization affects the local landscape and community (Alexis-Martin and Davies 2017; Anderson et al. 2019). This change in power is associated with racialization, changed mobilities and environmental (in)justices. Thus, the nuclear imperialism-necropolitics nexus provides a new framework for drawing together past, present and future humannuclear issues.

An important historical aspect of the nuclear imperialism-necropolitics nexus is nuclear imperialism. This is characterized by the capitalist formation, intervention and militarization of space, and by the ideological, cultural and material domination of one group, nation-state, or ideology by another, through nuclear means (Broinowski 2015). Nuclear imperialism arises due to the economic and spatial needs created by nuclear weapons and energy, as resources such as uranium are exploited, or spaces become militarized for nuclear weapon development and testing. The consequences of nuclear imperialism have been considered internationally, with studies including Ghana, the USA and the South Pacific (Allman 2008; Keown 2018; AlexisMartin 2019). Much of this prior research focuses on places that have been subject to Western colonization, creating a body of work that reveals a historical global network of injustice with ongoing repercussions, but that neglects to consider other spaces of colonization that are disconnected from the British Empire or the USA.

A significant contemporary element of the nuclear imperialism-necropolitics nexus is necropolitics. Mbembe's Necropolitics elucidates that, " ... race has been the ever present shadow in Western political thought and practice" 
$(2003,17)$. Clearly, this shadow of exclusion is not just confined to Western politics but also manifests itself in the contemporary racialization of Uyghur people in Xinjiang. As Uyghur spaces are dominated by nuclear activities for a second time, the nuclear has become inseparable from the technologies-ofcontrol pertaining to race and power, inscribing harmful new sets social and spatial relations on Uyghur people (Mbembe 2003; Foucault 1997). There are parallels between this long-term environmental racism and its necropolitical consequences in Xinjiang, and non-nuclear scenarios in the West. For example, studies have considered slow violence, necropolitics and petrochemical pollution in the Deep South USA; and have contemplated environmental racism as state-sanctioned racial violence and racialized capitalism in "multicultural corporate America" (Davies 2018; Pulido 2017, 527).

I argue that the Uyghur experience of environmental racism is extensive and extreme. I also posit that the post-Cold War Uyghur lifeworld has become the target of assault by the PRC, producing insidious forms of bare life (Agamben 1998; Habermas 2015). This is firstly due to historic nuclear imperialist neglect of indigenous communities in the PRC, and secondly, due to the actively necropolitical nature of ongoing environmental racism and cultural oppression. The PRC state vision of the Uyghur future currently is one that represents a secular ethnic group, thus restive Uyghur Muslim populations present a sense of existential threat to the social, cultural and economic aims of the PRC. Consequently, the PRC has undertaken oppressive measures to destroy the cultural aspects of Uyghur life (Habermas 2015). The UNHRC reported that "... the arbitrary detentions and the extensive use of surveillance technologies on Uyghurs violated their basic rights" (UNHRC, 2018). These acts create a state of exception and remove the possibility of an unhampered Uyghur lifeworld, which was previously constrained but intact, despite the consequences of Cold War nuclear imperialism.

Reports by international media including CNN, The Guardian and Quartz have described how Uyghur cultural figures have died whilst under detention, although limits on international scholarship and journalism in Xinjiang bring into question the reliability of these sources (Roberts 2018). On the 19 June 2019, The Guardian reported on the death of prominent Uighur writer Nurmuhammad Tohti after being held in one of Xinjiang's internment camps (Flood 2019). Prior to this, on February 2019, Quartz reported on the death of Uyghur poet and musician Abdurehim Heyit (Mollman 2019). This report declared that Turkey had lodged an unusual official protest over China's Uygur detention camps after Heyit's death, and described how the Turkish foreign ministry spokesperson Hami Aksoy said "It is no longer a secret that more than one million Uighur Turks incurring arbitrary arrests are subjected to torture and political brainwashing in internment camps and prisons" (Mollman 2019). Through a legacy of instrumentalization described across this paper, Uyghur experience has gradually become more necropolitical. It is also 
entangled with Agembe's notions of homo sacer, as Uyghur communities are now in " ... a continuous relationship with the power that banished him precisely insofar as he is at every instant exposed to an unconditional threat of death" (Agamben 1998). If international media reports are to be believed, then Uyghur homo sacer is subject to a state of exception by the means of state re-education and can be killed with impunity as a sacrificial object, whose death can be used to extend sovereign power.

Necropolitics is inherently a politics of death, whereby the state decides who will live and who must die, to create death worlds rather than lifeworlds (Mbembe 2003). It presents a framework to understand the instrumentalization of human existence, through the control of the lives and deaths of the subjugated, and the material destruction of human bodies and populations. The exercise of necropolitical power is in the taking away of "home", "body", and "political status", and in the direct "use" of lives (Mbembe 2003). Thus, it has previously provided relatable and relevant insights into how internment camps divest their inhabitants of political status and reduce them to a bare life (Mbembe 2003); and how the self-immolation of Tibetan monks can be understood as claiming agency over their own bodies to gain political status (Makley 2015). Necropolitics also gives insights into how unregulated toxic chemicals create "death-worlds", and how those who live with pollution experience these in temporally uncertain and constricting ways (Davies 2018). Thus, environmental racism arises from racial capitalism, when we consider the intersection between the long-term racialized oppression of Uyghur people and the use of their lands for nuclear weapon tests and uranium extraction (Pulido 2017).

This paper presents a reflective review of nuclear activity across Xinjiang, which centers on the multifarious ways that sovereign power has dominated and racialized Uyghur environments, culture and bodies. It provides a theoretical contribution to geography by considering the transition from nuclear imperialism to necropolitics, in the Uyghur context. The next section of this paper introduces the Uyghur people and provides an overview of relevant challenges faced by this community in Xinjiang. This is followed by a section that contemplates the impacts of Cold War nuclear imperialism to Uyghurs. This paper then explores entanglements between nuclear imperialism and necropolitics in Xinjiang, before turning to the complex and entwined contemporary necropolitical action against Uyghurs and its connections to economic and cultural development in the region. This paper concludes with an overview of the racially uneven nature of (in)justice that has arisen in Xinjiang, from the Lop Nor nuclear weapon tests to the present day.

\section{Introducing Xinjiang Uyghur autonomous region}

Xinjiang Uyghur Autonomous Region is a vast area of arid deserts and mountains in China, with an estimated population of 24.5 million people (Howell 
and Fan 2011). Xinjiang forms part of the Silk Road, bordering Kazakhstan, Russia, Mongolia, Kyrgyzstan, Tajikistan, Afghanistan, Pakistan and India (Grabot 1996). Among its multi-ethnic population are Uyghurs - who are one of 56 ethnic groups described by Minsu ethnonational categorization nationally (Xu'ai 2014). The Uyghur people are of Turkic Muslim origin and have been indigenous to Xinjiang for millennia (Tursun 2008). As such, the Uygurs form a unique Uyghur nation with its own homeland, history, habitus, Muslim religion, culture and language (Bovingdon 2010). However, this indigenous historical narrative is subject to ongoing contestation and disruption by China, who instead assert their sovereignty and dispute Uyghur indigenous territorial rights (Gladney 1998; Dillon 2002; Grose 2015). Thus, Xinjiang remains colonized, and Uyghur people contest the dominance of the Han state and its desire for a culturally homogenous people. Cultural homogeneity has progressed rapidly due to state-instigated Han migration. Between 1949 and 2008, the proportion of Han in Xinjiang rose dramatically from 6.7\% $(220,000)$ to $40 \%$ (8.4 million) (Howell and Fan 2011). For the subaltern Uyghur, the Han state aspiration for a universally secular and educated middleclass has been experienced as a process of Han occupation and suppression of Uyghur cultural identity by "re-education" (Gladney 1998).

Uyghur oppression is not a contemporary phenomenon. For 2,500 years, the region has broken away from China repeatedly. This space and its people were occupied by China's Qing dynasty in the eighteenth century and the region was renamed Xinjiang, meaning New Frontier (Swanström 2002). Xinjiang became a passageway for trade, and its borders with Kazakhstan and Pakistan have shaped its economic, cultural and political identity. While Uyghur independent rule arose in the 1930s and 1940s, it was not centrally planned and coordinated, and was characterized by interethnic competition and Soviet military support. In 1949, following victory in the Chinese Civil War, the People's Liberation Army (PLA) took control of Xinjiang and absorbed it into the newly formed People's Republic of China. A Han migration program began in 1950, prior to the designation of Xinjiang as a Uyghur autonomous region on the 1 October 1955 (Dillon 1997). Following its creation, there was an exodus of approximately 60,000 Uyghur and Kazakh people and their cattle to the Soviet Union from April to May 1962, in response to overarching cultural changes and the Han influx (Millward 2004). By the mid-1960s, nuclear weapon testing had begun in Xinjiang, and nuclear imperialism had emerged from existing Han colonization of Uyghur space.

\section{Cold war nuclear imperialism}

The PRC's actions toward Uyghur people in Xinjiang can be examined through the lens of nuclear imperialism. Nuclear imperialism has been used to describe scenarios where one state dominates another for nuclear purposes, such as 
French nuclear weapon testing in Algeria, or British nuclear weapon testing in the South Pacific during the Cold War (Alexis-Martin and Davies 2017). It is also a pertinent description of nuclear activities that are undertaken in the contested homelands of indigenous peoples, such as the historic consequences of uranium mining in the USA (Malin and Petrzelka 2010). The Uyghur community have experienced nuclear imperialism due to: contestations that surround the sovereignty of their homelands, the isolated and resource-rich nature of the space that they inhabit that has been claimed by the PRC, and the ideological differences that arise between their own and the state's sense of imagined community and national identity (Anderson 1991). China's state-sponsored national, regional, and nuclear site borders and zones have been imposed, affecting the geo-body of both Uyghur people and the state (Gladney 1998).

Xinjiang was selected to play a part in China's nuclear-weapons testing during the early 1960s. For 50 years, this space and its people have been affected by its place at the center of China's nuclear ambitions. China was the fifth nation to develop nuclear weapons during the Cold War, following the collapse of the Sino-Soviet nuclear relationship (McLane 1973). The PRC's nuclear defense development began in earnest after the Sino-Soviet split had annulled any residual myth of monolithic communism. Uranium mining for China's atomic bomb was first undertaken in Tibet before resources were discovered in Xinjiang (Evans 1962). It is not insignificant that Tibet, a stillcontested geography, played a vital role in the nuclear history of the PRC. Tibetan mining demonstrates how nuclear technology has long been linked to imperialism and the occupation of territory. The PRC established its first set of uranium mines and a milling plant, and large-scale military uranium prospecting projects were soon initiated in Xinjiang (Zhang and Bai 2015). In 1958, the Chinese settlement №404 Factory of China National Nuclear Corp was covertly built to refine plutonium and produce the components for nuclear weapons at the Lanzhou gaseous diffusion plant (Bonnett 2014). By June 1959, formal nuclear cooperation between the two communist states had ceased, but the PRC had decided to continue to pursue ownership of the atomic bomb without Soviet support (Jersild 2013). China formally established the $100,000 \mathrm{Km}^{2}$ Lop Nor Nuclear Test Base on the 16 October 1959, and it is still the largest site of its kind in the world (Norris 1996).

At $3 \mathrm{pm}$ on the 16 October 1964, the PRC undertook its first successful atomic bomb test at Lop Nor testing ground. A communiqué from Beijing asserted to the rest of the world that "The success of China's nuclear test is a major achievement of the Chinese people in the strengthening of their national defense and the safeguarding of their motherland, as well as a major contribution by the Chinese people to the cause of the defense of world peace" (Topping 1964). Despite US and Soviet apprehensions, this was the dawn of a new era of nuclear defense for the PRC. A further 22 atmospheric and 22 underground nuclear weapon tests were performed over the 
next 32 years in Lop Nur across Areas A (Nanshan); B (Qinggir); C (Beishan); and D (Drop Area) (Roberts, Manning, and Montaperto 2000). Nanshan was used for tunnel-based tests, Quinggir was the site of 13 underground tests, Beishan is located to the southwest of Quinggir and was used for two underground tests in 1969 and 1976, and the Drop Area is located south-east of Quinggir and was the site of atmospheric tests until 16 October 1980 (Roberts, Manning, and Montaperto 2000).

While the death of Mao Zedong in 1976 marked the end of the Cultural Revolution and ushered in a change in leadership focused on economic market liberalization and industrialization, the Lop Nor test facility remained uncompromised and unaffected by local activism (Millward 2004; Sovacool and Valentine 2010). A final underground tunnel test was undertaken at Area A in Lop Nur on the 29 July 1996, although there is some evidence that further underground tests were conducted in 2001 (Mian, Nayyar, and Ramana 2018). This final official test occurred just prior to the Comprehensive Test Ban Treaty (CTBT) opening for signatories, on the 24 September 1996 (UN, 2019). China is a CTBT and Nuclear Non-Proliferation (NNP) treaty participant but has yet to ratify the CTBT, a step that is mandatory for the Treaty's entry into force. It retains an estimated arsenal of 280 nuclear warheads (Kristensen and Norris 2018). China's nuclear weapon tests have had long-term implications for residents of Xinjiang, especially Uyghur people: the loss of their homelands and traditional way of life, environmental degradation, and health-related challenges (Roberts, Manning, and Montaperto 2000). All tests were undertaken across Uyghur homelands, exemplifying an aspect of internal colonialism to which Uyghur people have been subjected (Gladney 1998).

Lop Nor stands out among the most heavily contaminated nuclear weapon test sites, as airburst tests conducted during 1964-1980 exposed swathes of Xinjiang and eastern Kazakhstan to isotopes (Yamamoto et al. 2004). A study undertaken by Professor Jun Takada suggests that peak levels of radioactivity from the PRC's large-yield tests could have seriously affected local populations (Takada 2008). It is estimated that due to the prolonged nuclear weapon testing at Lop Nor, cancer incidence in the province is approximately 30-35\% higher than the state average (Merali 2009; Prăvălie 2014). PRC health data relating to Lop Nor have not been independently verified and is challenging to access outside of the state. However, journalists and medics have described a serious health legacy for Uyghurs in the areas surrounding the Lop Nor test site (Brown 1993; Merali 2009; Zeeya 2009). This includes a reported increase in cancer and congenital defects for children who live nearby the site since the 1970s, including tumors, leukemia and cleft palates, described by $\mathrm{Dr}$ Laura Watson to the Independent (Buncombe 1998). A Channel 4 Dispatches documentary attempted to learn more about possible health effects to this community (Death on the Silk Road 1999). This film showed a team of doctors and film-makers covertly posing as tourists in an 
attempt to assess the medical consequences of nuclear weapon testing in PRC. The filmmakers interviewed local doctors and offered medical services to the affected community, while illicitly collecting medical records to understand the health impacts. It revealed an impoverished community who have been affected by birth defects and health problems. While health data are limited, conditions for Uyghur people in the PRC mirror those of the indigenous communities in Kazakhstan and Australia who were subject Soviet and UK nuclear weapon tests and later experienced health effects (Alexis-Martin 2019).

In total, it is estimated that 60,000 people were exposed, many of whom would have been Uyghurs (Simon and Bouville 2002). However, it is difficult to ascertain whether the health effects they experienced are due to hereditary genetic mutations or to exposure to a contaminated environment (Alexis-Martin 2019). These issues are compounded by poor access to medical care, social services and necessary information about radiation health effects. Uygur traditional medicine is derived from Unani practices and is not adapted to treat any health challenges that may potentially arise from radiation exposure. Eyewitness accounts are limited but corroborate the existing literature. A Uyghur resident of Hiroshima Prefecture in Japan described his experience of living near Lop Nor, revealing that "In around 1989 and 1990, once or twice a year the sky darkened and pillows of sand and smoke grew, making me realise that they were conducting nuclear tests .... I went to the atomic bombing museum and learned for the first time that they could have an impact on human bodies" (Japan Times 2012). As witnesses to the destruction of their homes by the entangled relations of nuclear imperialism, first-nation indigenous representatives have demanded recognition of their prior ownership of lands and restitution for the damage done (Habermas 2015; Broinowski 2015).

For the Uyghur community, contestation and state assurances surrounding health risks serve to blur causation between exposure and illness, while a biopolitical regime shields the state and investors from liability (Broinowski 2015). No state compensation is forthcoming for down-winder Uyghur civilians who have been affected by the Lop Nor tests. Only Han former military personnel of the 8023 Force have received any support from the state for health problems that have arisen as a result of their work (Zeeya 2009). This imbalanced treatment only serves to strengthen tensions between the two communities.

In November 1985, Uyghur students in Beijing undertook peaceful protests against the nuclear weapon tests (Dillon 2002), which extended across Xinjiang's universities and colleges. The Urumchi student protest took place on 12 December 1985, as local universities also undertook peaceful protest. This included action in Kashgar (Kashi), Aqsu (Akesu), Hotan (Hetian), and Bortala (Bole), as approximately 15,000 students from different ethnic backgrounds participated (Rozinisa 2019). These peaceful protests had clear aims. Firstly, to promote democratic election in Xinjiang. Secondly, to stop the nuclear weapon tests. The third main aim was to stop Xinjiang serving as a large labor camp for China and to prevent unplanned immigration from 
other parts of China. Other aims included the implementation of autonomous law in Xinjiang, the elimination of one-child policy for Uyghur Muslims, and to develop cultural education across the region (Rozinisa 2019). Mr Aziz Isa Elkun, a nuclear test survivor from nearby Lop Nor who now lives in the UK, described his priorities as follows " ... to stop the nuclear tests, to stop implementing cultural genocide, to improve cultural education, and create equal rights with Han people" (Elkun 2019). When we spoke, he described to me how he produced a poster at high school as part of this peaceful movement, and how he was incarcerated by police for "... a few days", after his role in activism against PRC state was discovered. This small push-back against oppressive policies had some serious long-term implications for him as an adult, as he was later oppressed by state (Elkun 2019).

A serious incident occurred in 1989 when hundreds of Uyghur nationalists stormed Xinjiang's Great Hall of the People to demand greater political freedom and an end to nuclear weapon testing (Rodríguez 2013). In 1993, over a thousand people converged at Lop Nor to demand that the tests end, but they were shot at by PLA soldiers as the scene descended into violence, and vehicles and equipment were damaged (Dillon 2004). The most spectacular violence involved an organization called The Tigers of Lop Nor, who reportedly managed to blow up two airplanes and a number of tanks inside a nuclear zone (Grabot 1996). In the wake of the Strike Hard campaign of summer 1996, the governments of Kazakhstan and Kyrgyzstan moved to support China's clampdown on Uyghur separatists. The leader of Uyghur separatist group Attan, Amantay Asilbekov, was warned to stay at home on $28^{\text {th }}$ June during the visit of former Chinese President Jiang Zemin to Almaty, as his group had planned to stage a demonstration against China's nuclear test program at Lop Nor . In this socio-political environment, a Uyghur identity has emerged that has pushed back against Han nationalism to create a separatist and antinuclear movement. This represents the Uyghur's determination not to be ignored, despite challenges arising since the early Cold War. It is notable that Beijing finally ended nuclear weapon tests in 1996 due to international diplomatic pressures, rather than because of pressure from Uyghurs.

Proximity has meant that Uyghurs have witnessed the unshackling of their post-Cold War ethnic counterparts from their respective nuclear states, which has encouraged them to seek freedom from the dominant Han state and retain sovereign status (Bovingdon 2004, 2010). For states such as Kazakhstan, postSoviet re-bordering and sovereignty also meant voluntarily surrendering their prior nuclear weapon possessor status. Since 8 September 2006, some of these states have been part of a Central Asian Nuclear Weapon Free Zone (CANWFZ) abutting Xinjiang, including Kazakhstan, Kyrgyzstan and Tajikistan (Graham 2017). The PRC issued a statement on security assurances on 5 April 1995 that clarified a no-first-use policy, and specified non-use against any nonnuclear weapon states or nuclear-free zones (UN, 1995). Notably, the PRC 
specifically provided a letter on 8 February 1995 to Kazakhstan that stated " ... The Chinese Government has unconditionally undertaken not to use or threaten to use nuclear weapons against non-nuclear-weapon States or nuclear weapon-free zones. This long-standing principled position also applies to Kazakhstan ..." (UN 1995). This no-first-use statement was the first of its kind and demonstrated an awareness of both contemporaneous international nuclear geopolitics and the concerns of bordering nuclear-free and nonnuclear weapon possessor states. The presence of the CANWFZ also contrasts the nuclear statuses of nearby Pakistan and India, both of whom possess nuclear weapons. It is notable that while the PRC joined the International Atomic Energy Agency (IAEA) in 1984, it still supplied warhead design information and fissile for the development of Pakistan's nuclear program in the 1980s (Zhu 1997). Xinjiang, therefore, occupies a crucial strategic position, providing a buffer between the PRC and nuclear Pakistan, India and Russia.

\section{From nuclear imperialism to necropolitics}

The aftermath of nuclear imperialism in Lop Nor is well explained by Mbembe's theory of necropolitics (Mbembe 2003). The actions of the PRC in its control and subjugation of Uyghur people can be well described by his description of "weapons are deployed in the interest of maximum destruction of persons and the creation of 'death-worlds' ..." (Mbembe 2003, 40), referring to a "phantom-like" form of existence in which vast populations are subjected to the power of the state over their life and death. He also writes that "the extraction and looting of natural resources by war machines goes hand in hand with brutal attempts to immobilize and spatially fix whole categories of people" or even "to unleash them, to force them to scatter over broad areas no longer contained by the boundaries of a territorial state" (Mbembe 2003, pg., 34), which aptly portrays some of the impacts of PRC exploitation of Xinjiang, and it's subjugation of the people who live there. Necropolitics, therefore, provides the theoretical tools to understand the conditions that are imposed upon those who were exposed to contamination or forced to flee their homes, due to the Lop Nor nuclear weapon tests.

The exclusion of Uyghur people from state acceptance has been robustly depicted as an expression of Foucault's biopolitics, whereby this community symbolizes an almost biological threat to Chinese society that must be managed by surveillance, punishment, and detention (Foucault 1997; Roberts 2018). Foucault's living theories of biopower can be expanded upon to include the thinking of Achille Mbembe, who provides a powerful postcolonial critique of contemporary subjugation and the persistence of necropolitical regimes (Mbembe 2003). Whereas Foucault contends that "killing or the imperative to kill is acceptable only if it results not in a victory over political adversaries, but in the elimination of a biological threat ... to the species or race" (Foucault 
1997). I argue that the threats that the PRC perceives in Xinjiang are not just cultural, but also economic and political, and its actions against Uyghurs are distinctively necropolitical.

The politics of death, whereby state decides who will live and who must die, is well suited to understanding the nuclear history and current fate of Uyghurs in an era of banal securitization and terror. Mbembe posits that "To exercise sovereignty is to exercise control over mortality and to define life as the deployment and manifestation of power" (Mbembe 2003, 12). In the context of Uyghur people, their experiences are disciplinary, biopolitical and necropolitical, embedded by the state within shifting states of terror. A politics of cultural tokenism and social disposability surrounds Uyghurs. A racialized PRC protects Han economic and cultural interests while superficially celebrating Uyghur culture, yet simultaneously interring Uyghurs in cultural re-education camps (Giroux 2006; Zenz 2018). The damaged bodies of Uyghurs who have been affected by nuclearweapons testing, uranium extraction, and interment do just not speak with directness to the state of PRC racist violence but reveal and shatter illusions of racial equity in this region (Giroux 2006).

Recent state investment into nuclear energy projects is affecting Uyghurs by extending existing zones of exclusion, and reviving the contested nature of their homelands. In the 1990s, a civil nuclear energy renaissance coincided with a revival of nationalist sentiments, as both Soviet and Baltic states gained independence from their overarching prior state conglomerates (Budryte 2017). The high-profile nature of these events empowered other nationalist movements to gain independence and facilitated greater NGO intervention on the behalf of indigenous peoples (Bovingdon 2010). The events precipitated by the collapse of the Soviet Union, such as Kazakhstan gaining independence, meant that some Uyghurs gained the confidence to push for recognition of their collective identity. While they lacked the power to separate from the state, they found means to contest and challenge PRC state-building and undertake parallel representational politics (Bovingdon 2010). Three prominent Uyghur community leaders were killed between 1998 and 2001, but violent incidents within Xinjiang remained rare from 2001 to until 2008 (Millward 2004; Hastings 2011). Any violence may have been limited by increased securitization in the region during this time, potentially due to measures following an increased perception of threat from Muslim communities, including Uyghurs, after 9/11 initiated the Global War on Terror (GWOT) (Roberts 2012; Roberts 2018). However, the Ürümqi riots on 5 July 2009 saw clashes between protesting Uyghurs, Han people, and China's People's Armed Police, leaving nearly 200 people dead in Xinjiang (Cliff 2012). At least 40 people are reported to have disappeared during police sweeps in the days after the riots (Bristow 2019; Riley 2009). These scenarios provide demonstrable evidence of necropolitical rule over Uyghurs by the PRC. 


\section{Economic renaissance}

A key motivation for the contemporary regional oppression of Uyghurs is Xinjiang's ongoing strategic and economic importance. It is rich in resources and products, including oil, cotton, gas and tomatoes, and it forms a buffer against the West (NEA and IAEA 2016; Costa and Heuvelink 2018). Importantly, Xinjiang has become a place of civil nuclear industry, having reportedly placed a moratorium on fissile material production for nuclear deterrence (Zhang 2017). Uranium mining and milling constitute the first phase of any nuclearweapons program but are also essential for nuclear energy production. The PRC now derives a third of their uranium for nuclear energy from domestic extraction in the Yili basin of Xinjiang (OECD 2011; WNA 2019). The PRC is now working to ensure the use of Xinjiang spaces for civil nuclear energy in the form of uranium extraction and the future creation of a deep geological nuclear repository for PRCs nuclear waste. Meanwhile, the Red Mountain Institute defense laboratory continues to undertake nuclear research at the Northwest Institute for Nuclear Technology (NINT), to the north of the Lop Nor test site (NTI 2019). This has raised new issues have emerged surrounding the ongoing exclusion and detainment of Uyghurs.

The pursuit of civil nuclear industry in Xinjiang has extended and changed the nature of the necropolitical control of Uyghur people that began with military nuclear weapon testing. The PRC undertook an initial step toward nuclear renaissance in the 1980s as a shift occurred from military to civilian nuclear industrial activity, while a military-civil nuclear partnership remained (Zhang and Bai 2015). In 1980, the Lanzhou gaseous diffusion plant began to produce uranium for civilian purposes. By 1984, the Jiuquan military reactor was closed, and the Daya Bay reactor deal for the purchase of two French reactors was signed. However, nuclear ambitions remained modest during the 1980s. In 1987 the Heping gaseous diffusion plant ended highly enriched uranium production, and in 1991 the PRC closed the Guangyan plutonium production reactor. Uranium exploration was at a historic low (Zhang and Bai 2015).

When the military nuclear activity was de-prioritized, domestic uranium exploration and mining diminished from 1986 to 2003. The PRC became a signatory on both the Non-Proliferation Treaty (NPT) and CTBT (Zhang and Bai 2015). Its nuclear sector remained in a shrinking and adjustment phase. In the 2000s, however, the PRC's military-oriented nuclear program transitioned to meet increasing energy demands and to reduce carbon emissions. In March 2006, China's State Council approved the "Medium and Long-term Nuclear Power Development Plan (2005-2020)", which aimed to increase the PRC's nuclear capacity to about 40 GWe by 2020 (Zhou et al. 2011). In March 2009, the PRC demonstrated its commitment to peaceful nuclear energy by relocating the nuclear energy division of the State Administration of Science Technology and Industry for National Defense (SASTIND) to a newly 
established National Energy Bureau (NEB), and by implementing policies to encourage the growth of the nuclear economy. While PRC civilian nuclear energy is providing a welcome economic boost and employing a growing workforce, some concerns remain around public participation, and its transparency, regulation and management (DiMoia 2018).

This energy renaissance has significantly increased uranium exploration and extraction activities, with investment tripling between 2004 to 2012 (Zhang and Bai 2015). Exploration has been undertaken in geologically suitable regions with the capacity of in-situ leaching of uranium, including Xinjiang. There are currently 13 mines and six mills in operation, with estimated domestic uranium resources of 366,200 tons of uranium (tU) as of 2016 (NEA and IAEA 2016; Hibbs 2018). China is a uranium-rich country, and domestic uranium provides a third of the PRC's supply, with the remaining two-thirds sourced through the international market or from PRC-owned mines in Namibia, Niger and Kazakhstan (Hibbs 2018; DeBoom 2018). The 2016 Red Book identifies 366,000 tU in 21 deposits across 13 provinces, 39\% of the total in Inner Mongolia, 21\% in Jiangxi, 14\% in Xinjiang and 12\% in Guangdong (WNA 2019). CNNC's Geological Survey Bureau and the Beijing Research Institute of Uranium Geology are the key organizations involved with a massive increase in exploration effort since 2000. Extraction activities include those of uranium resources discovered in Xinjiang's Yili Basin in 2008, where the Yining (or Kujiltai) insitu leach (ISL) mine produces $380 \mathrm{tU} /$ year, operated by China National Uranium Corporation (CNUC or CUC), a subsidiary of CNNC (Hanham et al. 2018). A subsidiary setup in 2006, China Guangdong Nuclear Uranium Resources Co Ltd (CGN-URC), has been undertaking uranium exploration in Xinjiang, and announced that it was developing two $500 \mathrm{tU} /$ year mines in this region in 2013 (WNA 2019). PRC uranium demand is anticipated to grow by $7.69 \%$ per year, until domestic uranium production peaks in 2065 (Fang et al. 2018).

Due to regional regulatory arbitrage and no overarching nuclear legislation currently being in place in PRC, there are few incentives for rigorous monitoring and safety programs at the "internal colony" based uranium extraction sites, such as Xinjiang's Yili Basin. The "2003 Law on the People's Republic of China on the Prevention and Control of Radioactive Pollution" specifies that state council environmental protection authorities are required to supervise and inspect measures to prevent radioactive pollution at nuclear facilities and during the development of uranium mines (OECD, 2011; Patton Schell 2014). However, Article 12 of this law holds "units" rather than entities responsible for radioactive pollution, meaning that if an accident should occur then the blame would fall upon a set of individuals rather than a corporation or organization (Patton Schell 2014). This decreases the motivation of organizations such as CNNC to ensure that existing regulations are followed, reducing protections to workers. Natural uranium remains unregulated, except in large batches, under existing international agreements. Thus, the exposure and replacement of workers provide a bulwark to absorb the violence of uranium capital accumulation (Broinowski 2015). 
After 2008, the PRC shifted from active to aggressive development. As of September 2018, China has 44 nuclear reactors in operation and 18 under construction, and hopes to continue to expand nuclear energy production until a fifth of its energy originates from nuclear power plants by 2030 (Hibbs 2018; Sheng 2018). While activism in Xinjiang is blamed on nationalism and Islamism rather than legacy or contemporary activities of the nuclear industry, anti-nuclear activism is now also arising in the East, in Rushan in Shandong Province, Lianyungang in Jiangsu Provence, Pengze in Jiangxi Provence and Jiangmen in Guangdong Provence (Sheng 2018). This activism is occurring due to community concerns that the environment and health will not be protected by a cohesive and overarching nuclear energy policy. Anti-nuclear activists use a combination of resistive media strategies to prevent local nuclear power plant placement, including online petitions to influence public opinion (Sheng 2018; Gu 2015). However, the xinfang administrative petition system for hearing complaints from individuals in the PRC provides limited influence and access to governance (Minzner 2006). These communities, therefore, use the connections of their participants to send their concerns directly to the PRC central government (Sheng 2018). The PRC engages in censorship to maintain control over the media, and also uses the internet to collect public information and strengthen its rule within the Great Firewall (Brady 2017). Petitioners in the east of China are often well educated and familiar with the political system, and are able to negotiate local change. The central government will, therefore, change the location of a nuclear power plant at the expense of less influential and resistant communities (Sheng 2018). While some communities have demonstrated empowered and successful mobilization against new nuclear power plants in their region, they are unconcerned with the successor communities who receive the plant in their stead, and are unaware of the entangled intranational network whereby new nuclear energy in the East is fuelled by uranium extraction and milling in the West of the PRC.

\section{Contemporary cultural oppression}

It is important to consider the contemporary challenges and contestations of Uyghur Muslim identity. Twenty years ago, Gladney considered the cultural implications of nationalist governance in China, questioning what would happen to " ... those citizens on its borders, should a nationalist movement rise up that sees them as more of a threat, than as a part of China that is multinational and multi-ethnic" (Gladney 1998). Increasingly, Uyghurs are portrayed by the PRC as terrorists who are against state values (Millward 2018).

The universal nature of a perceived Islamist threat, and its intersection with the Global War on Terror (GWOT), means that it serves as a powerful justification for heavy regional securitization in Xinjiang (Roberts 2018). Since 2017, these measures have included an extensive and punitive political re-education 
campaign, involving the widespread surveillance and the detainment of Uyghur people for re-education (Zenz 2018). The PRC counter-narrative for this action suggests that it may be winning the "propaganda war", as many countries and Muslim organizations have remained silent about this mass detention (Huang 2019). This recent turn of events is the pinnacle of a long legacy of state anti-separatism campaigns since the 1930s (Dillon 1997). These measures are contributing to the cultural genocide of Uyghur people by depriving them of their integrity as distinct peoples, and of their cultural values and ethnic identities (UN 1994; Bewicke 2009).

"Cultural genocide" is described as any action that deprives an ethnic group's integrity as distinct individuals or of their cultural values or ethnic identities. It is any action which has the aim or effect of dispossessing them of their lands, territories and resources; any form of population transfer that has the aim of effect of violating or undermining any of their rights; any form of assimilation or integration by other cultures or ways of life imposed upon them by legislative, administrative or other measures; or any form of propaganda directed against them (UN 1994). While some aspects of this definition are enshrined in indigenous peoples' rights, currently neither the Convention on the Prevention and Punishment of the Crime of Genocide nor the Universal Declaration of Human Rights protects against cultural genocide (Morsink 1999; UN 2018). In Xinjiang, in addition to persecution and re-education, cultural genocide is achieved by flooding Uyghur communities with Han migrants, who are economically incentivized to migrate to these regions (Côté 2015). The dominance of Han migrant communities has exacerbated existing ethnic tensions, due to disparities in socioeconomic status and Han dominance of local economy and politics. Notably, re-education measures since the early $2000 \mathrm{~s}$ have made it difficult for young people to resist integration into Han culture, as all schools in Xinjiang emphasize Chinese language instruction, with all Uyghur language teaching ceasing at Xinjiang University by 2002 (Grose 2010).

However, a separatist Uyghur identity has persisted that rejects PRC nationalism, and that has become increasingly radical as surveillance measures extend. Uyghur community separatism is not a new phenomenon, and Uyghurs argue that their attachment to their homelands and their extensive regional history justify their stance (Gladney 1998). While Uyghur people have been othered due to their cultural preferences, observable aesthetic and physiognomic differences between Uyghur and other Chinese citizens create exigent circumstances whereby Uygur people are biologically set apart from the rest of the state (Roberts 2018). This means that Uyghurs are easily stigmatized and targeted for re-education or punishment due to their appearance, regardless of their compliance with Han cultural ideologies.

Although the small number of active Uyghur separatists have remained vastly outnumbered by the People's Army and the People's Police (Zenz 2018), there has been a significant increase in the frequency and intensity of violent incidents in 
the Xinjiang Uyghur Autonomous Region in the $21^{\text {st }}$ century (Dillon 2018). While there is limited evidence of widespread Uyghur involvement in either Al Quaeda or Taliban forces, extensive clandestine de-extremification work has been undertaken by the PRC. Since Spring 2017, Xinjiang has witnessed the emergence of an unprecedented re-education campaign, with an estimated one million Uyghurs and other Muslims being detained by the state (Zenz 2018; Millward 2018; BBC 2019). This has major implications for society, local economies and ethnic relations, as it removes the opportunity for Uyghurs to be considered anything other than unlawful and illegitimate (Millward 2018). The justifications for this action by the PRC stem from the post 9/11 perception of political Islam. Some 22 Uyghurs were incarcerated in Guantanamo Bay in the aftermath of 9/11, sparking international concern about the perceived problems of militant Uyghur Islamism, and its associations with the Taliban and Al Quaeda (Shichor 2005). Despite those engaging in terrorism not being representative of the vast majority of Uyghur people, a War on Terror has emerged in the PRC, and efforts were made to suppress separatism (Giglio 2004). The political oppression of Uyghur people was made possible by this opportunity to criminalize their ethnicity by representing this community as being terrorists against the values of the state (Becquelin 2004).

The persecution of Uyghur separatists as terrorists has protected several economic advantages beyond the nuclear spaces of Xinjiang and has been described as terror capitalism (Byler 2018). This has been motivated by the increased neoliberalization of the PRC's economy and represents a postsocialist transition. It is evidenced by the way that state-directed economic investment in the region has been paralleled by further security infrastructure for managing the presence of Uyghur bodies and ideologies. Surveillance is physical, electronic and biological. A database of Xinjiang DNA has been established by requiring genetic samples from all those who apply for passports (Human Rights Watch 2017; Dillon 2018; Roberts 2018; UN 2018). This merging of biological data and electronic surveillance has the aim of protecting state politics and economy, and exceeds anything described in Foucault's original articulation of biopolitics (Foucault 1997; Roberts 2018). An increasingly authoritarian politic has emerged in the PRC, governing through economic rather than social terms, and operates alongside technologies of discipline and the power to make live - or die (Giroux 2006). This is demonstrated by recent decisions made by a Han-dominant local government. Since the 2016 appointment of Chen Quanguo as Communist Party Secretary, Xinjiang has become a regional panopticon within a security state (Roberts 2018). This has increased the precarity of an existing bare life for Uyghurs, for whom life is "constantly rendered in its precariousness, a life that is always potentially under attack, and therefore always an exceptional life" (Thacker 2011, 158). This bare life is produced for Uyghur people under the threat and force of economically motivated necropower, which then reproduces the ongoing justification, normalization, and banality of the PRC's exceptional 
necropolitical rule over Uyghur bodies and lives (Mbembe 2003; Arendt 2002). Thus, the politics that surrounds Uyghur separatist lives has been embedded in invisible relations of power under a local regime of exceptional surveillance and insecurity.

In 2012, China unveiled a plan in collaboration with Beijing's Tsinghua University and the local government to turn the Lop Nor nuclear test site into a "red tourism site", with funding for this requalification project to make the location tourist-friendly (BBC 2012). The development of tourism opportunities reflects the increased cultural opportunities and disposable incomes available to many, as the overarching Chinese economy has boomed. Visitors will be able to view scientist's laboratories and a 300-m tunnel that was used for airstrikes, as part of a program of spaces designated by the PRC to celebrate its military history (Cappelletti 2015). This appropriation of land by the PRC for the celebration of its military achievements represents a final phase of military nuclear imperialism, continuing a legacy of occupation and control of space, and the subjugation or removal of the people who live there.

Xinjiang remains of strategic value as a buffer zone and for its commodities. However, it has also featured as a potential site for a future nuclear waste repository for spent nuclear fuel. Global contestations have occurred regarding the placement of such repositories internationally, and US and Australian repository programs have stalled due to long-term safety concerns and nimbyism (Apted and Ahn 2017). Since the start of its civilian nuclear power program, the PRC has pursued an R\&D program for a final high-level nuclear waste (HLW) repository (Brunnengräber et al. 2018). Large civilian nuclear energy programs generate nuclear waste, and the Northwest Institute for Nuclear Technology (NINT) in Xinjiang has undertaken research into a potential HLW repository and underground research laboratory facility (URL) in the region since 2012 (Di Nucci et al. 2018). The final site selection is still pending but has been narrowed down to the Aquisha area, nearby to Lop Nor, which has no permanent residents. There is currently no literature that explores or describes nomadic residents or the cultural significance of this site. Executive nuclear waste management legislation is currently uneven, as China has no overarching legislation that requires nuclear power plant operators to manage nuclear waste liabilities (Di Nucci et al. 2018). Although nuclear safety issues have received attention in PRC since Fukushima, there has been less attention to nuclear waste management. With onsite storage pools reaching their capacity, the PRC will need more facilities for the safe long-distance transport and offsite interim storage of spent fuel from 2020 (Brunnengräber et al. 2018).

There is currently cooperation between the US and China on underground laboratory-based studies, despite the PRC's concerning human rights track record in the region (Normile 2009). However, in 2018 the US considered placing sanctions on PRC due to their treatment of Uyghurs (UN 2018; Kuo 2018). Sanctions, if any, could be imposed under the Global Magnitsky Act, 
which allows the US government to freeze US assets of human rights violators and prohibit US economic collaboration (Firestone and Contini 2018).

Xinjiang is a core hub of PRC's nuclear sector, and the PRC seems determined to pursue an oppressive solution to its challenges surrounding Uyghur people. Until international intervention arises, Xinjiang remains a necropolitical space where the "... the lines between resistance and suicide, sacrifice and redemption, martyrdom and freedom are blurred." (Mbembe 2003, 40).

\section{Conclusions}

The ongoing pursuit of uranium extraction and nuclear waste storage in Xinjiang Uyghur Autonomous Region connects historic nuclear imperialism in the form of nuclear weapon testing to contemporary nuclear industrial and state expansion that bears necropolitical traits. The Uyghur people were originally witnessed to the destruction of their life-worlds during the nuclear imperialism of the PRC's Cold War nuclear weapon tests, yet have had their demands for recognition of their lands and their claims for restitution of damage ignored. Anti-nuclear activism is not often presented as a central element of Uyghur political movements, as it has been overshadowed by the many other injustices that this community has faced in China. However, it does form an important explanatory element for the PRC's territorializing and security practices in Xinjiang.

While reassurances of no-nuclear first use have been recently reaffirmed by the PRC, it retains an internal population of people who have been harmed by its historic nuclear experimentation. The value of uranium and its current contribution to energy generation and carbon emission reduction continue to be prioritized by the PRC over the collective cultural and material autonomy and rights of Uyghur people. I suggest that rather than being a comparatively peripheral issue, the contemporary presence of the renewed nuclear industry in Xinjiang deserves further scrutiny by human geographers, as it plays a neglected role in Uyghur activism and land rights contestations.

I argue that the present Uyghur situation in China has arisen due to a troika of othering, biopolitical surveillance, and necropolitical action that is designed to gain state control over this community and is associated with the aftermath of both historic nuclear weapon testing and the GWOT. This is despite the PRC's political discourse purporting to support Uyghur culture, while simultaneously framing this community as terrorists. Motivations for these conflicted and complex interactions include the state's desire to maintain Xinjiang's strategic borders and spaces, and thus retain its nuclear geopolitical and economic advantages.

The decreased instances of violence in Xinjiang and increased surveillance and cultural re-education in 2016 to 2017 have coincided with a further affirmation of Xinjiang's renewed significance as a nuclear region. For instance, accelerated site 
selection for a High-Level Waste nuclear repository is ongoing at Yamansu in Xinjiang Uygur Autonomous Region since 2012 (Wang 2014; Lui and Pan 2016). The future storage of nuclear waste within indigenous lands that are currently used for uranium extraction may not sit comfortably with Uyghur people, if this scenario does arise. There is an urgent need for PRC to reflect upon its current policies pertaining to indigenous people, to ensure that it does not perpetuate the second phase of nuclear imperialism. A civil nuclear energy renaissance in the PRC offers important international economic and climate change mitigation benefits, but it must not be at the expense of Uyghur people. Uyghur lives have been instrumentalized for the purposes of sovereign power over life and death. However, it is difficult to know if this was the intention of state power from the first moment of nuclear weapon testing, or an unintended consequence of nuclear imperialism. It may simply be that Uyghur lives did not matter and continue to not matter, from the perspective of state.

In this paper, I have reviewed the significance of nuclear imperialism, cultural genocide and necropolitics, offering insights into the ways that nuclear issues are inherently geopolitical and humanitarian in nature. I explored the geographic links between historic nuclear imperialism and contemporary necropolitics through the case of Uyghur-PRC nuclear geographies, which illustrates the existence of a nuclear imperialism-necropolitics nexus. This paper is not an exhaustive review of the nuclear geographies of China and offers considerable opportunities for further development. The nuclear imperialism-necropolitics nexus also provides a framework for examining and analyzing events occurring outside of Xinjiang. This includes the development of nuclear energy in the East of the PRC, but it also extends across the Eurasian region to the consideration of uranium mining in Kazakhstan, and to the nuclear weapon and energy geopolitics of Russia, India and Pakistan. It has transnational implications beyond Eurasia, to anywhere that has a legacy of nuclear weapon testing and nuclear energy development.

\section{Disclosure statement}

No potential conflict of interest was reported by the author.

\section{ORCID}

Becky Alexis-Martin (D) http://orcid.org/0000-0002-8130-7543

\section{References}

Agamben, G. 1998. Homo Sacer: Sovereign Power and Bare Life. Stanford University Press. Stanford, CA, USA.

Alexis-Martin, B. 2019. Disarming Doomsday: The Human Impacts of Nuclear Weapons since Hiroshima. Pluto Press. London, UK. ISBN: 0745339204. 
Alexis-Martin, B., and T. Davies. 2017. "Towards Nuclear Geography: Zones, Bodies, and Communities." Geography Compass 11 (9): e12325. doi:10.1111/gec3.v11.9.

Allman, J. 2008. "Nuclear Imperialism and the pan-African Struggle for Peace and Freedom: Ghana, 1959-1962." Souls 10 (2): 83-102. doi:10.1080/10999940802115419.

Anderson, B. 1991. Imagined Communities: Reflections on the Origin and Spread of Nationalism. 1st ed. 1983, London: Verso Press.

Anderson, B., K. Grove, L. Rickards, and M. Kearnes. 2019. "Slow Emergencies: Temporality and the Racialized Biopolitics of Emergency Governance." Progress in Human Geography. In Press

Apted, M. J., and J. Ahn, eds.. 2017. Geological Repository Systems for Safe Disposal of Spent Nuclear Fuels and Radioactive Waste. Woodhead Publishing. Cambridge, MA, USA

Arendt, H. 2002. Eichmann in Jerusalem: A Report on the Banality of Evil. On Genocide; an Anthropological Reader. Eds. Alexander Laban Hinton. Oxford: Blackwell Publishing.

BBC. 2012. "China to Open Atomic Bomb Site to Tourists. British Broadcasting Corporation News." October 16th, 2012. Accessed 8th Feb 2019.

BBC. 2019. "Turkey Demands China Close Camps after Reports of Musician's Death." February 10th, 2019. Accessed 10th Feb 2019.

Becquelin, N. 2004, April. "Criminalizing Ethnicity: Political Repression in Xinjiang." China Rights Forum 1 (7): 36-39.

Bewicke, A. E. 2009. "Silencing the Silk Road: China's Language Policy in the Xingjiang Uyghur Autonomous Region." San Diego Int'l LJ 11: 135.

Bonnett, A. 2014. Unruly Places: Lost Spaces, Secret Cities, and Other Inscrutable Geographies. Houghton Mifflin Harcourt. Boston, MA, USA.

Bovingdon, G. 2004. "Autonomy in Xinjiang: Han Nationalist Imperatives and Uyghur Discontent." Policy Studies 11: I.

Bovingdon, G. 2010. The Uyghurs: Strangers in Their Own Land. Columbia University Press. New York, USA.

Brady, A. M. 2017. "Plus Ça Change?: Media Control under Xi Jinping." Problems of PostCommunism 64 (3-4): 128-140. doi:10.1080/10758216.2016.1197779.

Bristow, M. 2019. "Many 'missing' after China Riots". BBC News, October 21st, 2009. Retrieved 22nd June 2019.

Broinowski, A. 2015. "Nuclear Imperialism." Palgrave McMillan. Accessed 5th Feb 2019.

Brown, W. 1993. "Chinese Test Site Forced into Public View." New Scientist, October 2nd, 1992. Accessed 9th Feb 2019.

Brunnengräber, A., M. R. Di Nucci, A. M. I. Losada, L. Mez, and M. A. Schreurs, eds.. 2018. Challenges of Nuclear Waste Governance: An International Comparison. Vol. 2. Springer. New York, USA.

Budryte, D. 2017. Taming Nationalism? Political Community Building in the post-Soviet Baltic States. Routledge. Abingdon-on-Thames, UK.

Buncombe, A. 1998. "China's Secret Nuclear Tests Leave Legacy of Cancer and Deformity." The Independent, October 5th, 1998. Accessed 9th Feb 2019.

Byler, D., 2018. "Spirit Breaking: Uyghur Dispossession, Culture Work and Terror Capitalism in a Chinese Global City." Doctoral dissertation, University of Washington.

Cappelletti, A. 2015. "Developing the Land and the People: Social Development Issues in Xinjiang Uyghur Autonomous Region (1999-2009)." East Asia 32 (2): 137-171. doi:10.1007/s12140-015-9240-8.

Cliff, T. 2012. "The Partnership of Stability in Xinjiang: State-Society Interactions following the July 2009 Unrest." The China Journal (68): 79-105. doi:10.1086/666581.

Costa, J. M., and E. Heuvelink. 2018. The Global Tomato Industry. Boston (EEUU): CABI. 
Côté, I. 2015. "The Enemies Within: Targeting Han Chinese and Hui Minorities in Xinjiang." Asian Ethnicity 16 (2): 136-151. doi:10.1080/14631369.2015.1003688.

Davies, T. 2018. "Toxic Space and Time: Slow Violence, Necropolitics, and Petrochemical Pollution." Annals of the American Association of Geographers 108 (6): 1537-1553. doi:10.1080/24694452.2018.1470924.

Death on the Silk Road 1999.[Documentary]. Richard Hering and Stuart Tanner dir. UK. Channel Four Dispatches.

DeBoom, M. J. 2018. "Nuclear (geo) Political Ecologies: A Hybrid Geography of Chinese Investment in Namibia's Uranium Sector." Journal of Current Chinese Affairs 46 (3): 53-83. doi:10.1177/186810261704600303.

Di Nucci, M. R., A. M. I. Losada, M. A. Schreurs, A. Brunnengräber, and L. Mez. 2018. "The Technical, Political and Socio-Economic Challenges of Governing Nuclear Waste." In Challenges of Nuclear Waste Governance, edited by Achim Brunnengräber et al., 3-22. Wiesbaden: Springer VS.

Dillon, M. 1997. "Ethnic, Religious and Political Conflict on China's Northwestern Borders: The Background to the Violence in Xinjiang." IBRU Boundary and Security Bulletin 5 (1): $80-86$.

Dillon, M. 2002. "Uyghur Language and Culture under Threat in Xinjiang." [central AsiaCaucasus Analyst]. August 14. accessed 28th January 2019. http://coranet.radicalparty. org/pressreview/print.php?func=detail\&par $=2862$,

Dillon, M. 2018. Xinjiang in the Twenty-First Century: Islam, Ethnicity and Resistance. Routledge. Abingdon-on-Thames, UK.

DiMoia, J. P., Edited by. 2018. "Nuclear Debates in Asia: The Role of Geopolitics and Domestic Processes." Mike M. Mochizuki and Deepa M. Ollapally. Pacific Affairs 91 (1):119-121.

Elkun, A. I., 2019. "Interview with Dr Becky Alexis Martin about His Personal Experiences of Living near Lop Nor." June 16th, 2019. Transcript available from b.alexis-martin@mmu.ac.uk

Evans, G. H. 1962. "China and the Atom Bomb-l." Royal United Services Institution. Journal 107 (625): 30-34. doi:10.1080/03071846209423481.

Fang, J., C. K. M. Lau, Z. Lu, and W. Wu. 2018. "Estimating Peak Uranium Production in China-Based on a Stella Model." Energy Policy 120: 250-258. doi:10.1016/j. enpol.2018.05.049.

Firestone, T., and K. Contini. 2018, December. "The Global Magnitsky Act." Criminal Law Forum. Vol. 29, No. 4, 617-628. Netherlands: Springer.

Flood, A. 2019. "Uighur Author Dies following Detention in Chinese 're-education' Camp." The Guardian, June 19th, 2019. Accessed 24th June 2019.

Foucault, M. 1997. Society Must Be Defended": Lectures at the College De France, 1975-76. New York, NY: Picador Press.

Giglio, D. 2004. Separatism And The War On Terror In China's Xinjiang Uighur Autonomous Region. Thesis, UN Peace Operations Training Institute

Giroux, H. A. 2006. "Reading Hurricane Katrina: Race, Class, and the Biopolitics of Disposability." College Literature 33 (3): 171-196. doi:10.1353/lit.2006.0037.

Gladney, D. C. 1998. "Internal Colonialism and the Uyghur Nationality: Chinese Nationalism and Its Subaltern Subjects." Cahiers d'Etudes sur la Méditerranée Orientale et le monde Turco-Iranien (25).

Grabot, A. 1996. "The Uyghurs - Sacrificed on Central China's Chess Board." Agent FrancePresse, Paris, France. April 25th, 1996.

Graham, T. 2017. The Alternate Route: Nuclear-Weapon-Free Zones. Oregon State University Press. Grose, T. 2010. "The Xinjiang Class: Education, Integration, and the Uyghurs." Journal of Muslim Minority Affairs 30 (1): 97-109. doi:10.1080/13602001003650648. 
Grose, T. 2015. "(re)embracing Islam in Neidi: The 'xinjiang Class' and the Dynamics of Uyghur Ethno-National Identity." Journal of Contemporary China 24 (91): 101-118. doi:10.1080/10670564.2014.918408.

Gu, H. 2015. "NIMBYism in China: Issues and Prospects of Public Participation in Facility Siting." Land Use Policy 52: 527-534. doi:10.1016/j.landusepol.2014.12.015.

Habermas, J. 2015. The Theory of Communicative Action. Lifeworld and Systems, a Critique of Functionalist Reason. Vol. 2. John Wiley \& Sons. Hoboken, NJ, USA.

Hanham, M., G. Liu, J. Rodgers, M. Best, S. Milne, and O. Lepinard 2018. "Monitoring Uranium Mining and Milling in China and North Korea through Remote Sensing Imagery." CNS Occasional Paper 40, October, 2018. James Martin Center for Nonproliferation Studies. Accessed 9th Feb 2019.

Hastings, J. V. 2011. "Charting the Course of Uyghur Unrest." The China Quarterly 208 (December): 893-912. doi:10.1017/S0305741011001056.

Hecht, G. 2012. Being Nuclear: Africans and the Global Uranium Trade. MIT Press. Cambridge, MA, USA.

Hibbs, M. 2018 May. The Future of Nuclear Power in China. Carnegie Endowment for International Peace.Washington DC, USA.

Howell, A., and C. C. Fan. 2011. "Migration and Inequality in Xinjiang: A Survey of Han and Uyghur Migrants in Urumqi." Eurasian Geography and Economics 52 (1): 119-139. doi:10.2747/1539-7216.52.1.119.

Huang, J. 2019. "Rights Activists Denounce China's Xinjiang White Paper." VOA News, March 19, 2019. https://www.voanews.com/east-asia/rights-activists-denounce-chinasXinjiang-white-paper

Human Rights Watch. 2017. "China: Police DNA Database Threatens Privacy, 40 Million Profiled Includes Dissidents, Migrants, Muslim Uyghurs." Accessed February 3: 2019.

Japan Times. 2012. "China Nuclear Tests Prompt Uighur Campaign." August 9th, 2012. Accessed 9th Feb 2019.

Jersild, A. 2013. "Sharing the Bomb among Friends: The Dilemmas of Sino-Soviet Strategic Cooperation". Cold War International History Project, Wilson Center. Accessed 4th Feb 2019.

Keown, M. 2018. "Waves of Destruction: Nuclear Imperialism and Anti-nuclear Protest in the Indigenous Literatures of the Pacific." Journal of Postcolonial Writing 54 (5): 585-600. doi:10.1080/17449855.2018.1538660.

Kristensen, H. M., and R. S. Norris. 2018. "Chinese Nuclear Forces, 2018." Bulletin of the Atomic Scientists 74 (4): 289-295. doi:10.1080/00963402.2018.1486620.

Kuo, L. 2018. "US Considers Sanctions on China over Treatment of Uighurs." The Guardian, September 12th, 2018. Accessed 10th Feb 2019.

Lui, and Pan. 2016. High Level Wastes Disposal Solution in China. Topical Meeting: Challenges and Responsibilities of Multinational Radioactive Waste Disposal Facilities. CNNC. Vienna, Austria, Sept 6, 2016. Accessed 5th Feb 2019.

Makley, C. 2015. "The Sociopolitical Lives of Dead Bodies: Tibetan Self-immolation Protest as Mass Media." Cultural Anthropology 30 (3): 448-476. doi:10.14506/ca30.3.

Malin, S. A. 2015. The Price of Nuclear Power: Uranium Communities and Environmental Justice. Rutgers University Press. New Brunswick, NJ, USA.

Malin, S. A., and P. Petrzelka. 2010. "Left in the Dust: Uranium's Legacy and Victims of Mill Tailings Exposure in Monticello, Utah." Society and Natural Resources 23 (12): 1187-1200. doi:10.1080/08941920903005795.

Mbembe, A. 2003. "Necropolitics." Public Culture 15 (1): 11-40. doi:10.1215/08992363-15-1-11. McLane, C. B. 1973. Soviet-Asian Relations. Vol. 2. London: Central Asian Research Centre. 
Merali, Z. 2009. "Did China's Nuclear Tests Kill Thousands and Doom Future Generations." Scientific American 301(1), 16-17.

Mian, Z., A. H. Nayyar, and M. V. Ramana. 2018. "The Twenty Years' Crisis of Nuclear South Asia, 1998-2018: A Workshop Report." Journal for Peace and Nuclear Disarmament 1 (2): 529-535. doi:10.1080/25751654.2018.1527807.

Millward, J. 2018. "What It's like to Live in a Surveillance State." New York Times, February 3. Accessed 3 February 2019.

Millward, J. A., 2004. Violent separatism in Xinjiang: a critical assessment.

Minzner, C. F. 2006. "Xinfang: An Alternative to Formal Chinese Legal Institutions." Stan. J. Int'l L. 42: 103.

Mollman, S. 2019. "Watch: The Musician Turkey Mourns in Its Protest of China's Uyghur Detention Camps." Quartz, February 10 $0^{\text {th }}, 2019$. Accessed 24th June 2019.

Morsink, J. 1999. "Cultural Genocide, the Universal Declaration, and Minority Rights." Human Rights Quarterly 21 (4): 1009-1060. doi:10.1353/hrq.1999.0052.

NEA and IAEA. 2016. Uranium 2016, p. 207.

Normile, D. 2009. "Particle Physics. Chinese Scientists Hope to Make Deepest." Darkest Dreams Come True. Science (new York, NY) 324 (5932): 1246. doi:10.1126/science.324_1246.

Norris, R. 1996. "French and Chinese Nuclear Weapon Testing." Security Dialogue 27: 48. doi:10.1177/0967010696027001006.

Nuttall, W. J. 2004. Nuclear Renaissance: Technologies and Policies for the Future of Nuclear Power. CRC Press. Boca Raton, FL, USA.

Patton Schell, T., 2014. "Governing Uranium in China." (No. 2014: 03). DIIS Reports, Danish Institute for International Studies.

Pitkanen, L., and M. Farish. 2018. "Nuclear Landscapes." Progress in Human Geography 42 (6): 862-880. doi:10.1177/0309132517725808.

Prăvălie, R. 2014. "Nuclear Weapons Tests and Environmental Consequences: A Global Perspective." Ambio 43 (6): 729-744. doi:10.1007/s13280-014-0491-1.

Pulido, L. 2017. "Geographies of Race and Ethnicity II: Environmental Racism, Racial Capitalism and State-sanctioned Violence." Progress in Human Geography 41 (4): 524-533. doi:10.1177/0309132516646495.

United Nations. 2018. Report of the Office of the United Nations High Commissioner for Human Rights. "Human Rights Council Working Group on the Universal Periodic Review." Thirty-first session. November 5-16, 2018. Accessed 23rd June 2019.

Riley, A. 2009. "China Officials 'disappeared' Uighurs after Xinjiang Riots: HRW“. Paper Chase Newsburst. University of Pittsburgh School of Law. October 21th, 2009. Accessed 22nd June 2019.

Roberts, B., R. A. Manning, and R. N. Montaperto. 2000. "China: The Forgotten Nuclear Power." Foreign Aff. 79: 53. doi:10.2307/20049808.

Roberts, S. R., 2012. "Imaginary Terrorism? the Global War on Terror and the Narrative of the Uyghur Terrorist Threat." PONARS Eurasia Working Papers..

Roberts, S. R. 2018. "The Biopolitics of China's "war on Terror" and the Exclusion of the Uyghurs." Critical Asian Studies 50 (2): 232-258. doi:10.1080/14672715.2018.1454111.

Rodríguez, P. A. 2013. "Violence Resistance in Xinjiang (china): Tracking Militancy, Ethnic Riots and "knife-wielding" Terrorist (1978-2012)." Historia Actual Online 30: 135-149.

Rozinisa. 2019. "The True Story of a Uyghur Youth Who Was a Victim of the "12 December Student Protest" in Urumch." January 10th, 2019. http://www.azizisa.org/en/elkun12december-student-protest/\#more-704

Sheng, C. 2018. "Petitioning and Social Stability in China: Case Studies of Anti-nuclear Sentiment." VOLUNTAS: International Journal of Voluntary and Nonprofit Organizations, 30(2), 381-392 
Shichor, Y. 2005. "Blow Up: Internal and External Challenges of Uyghur Separatism and Islamic Radicalism to Chinese Rule in Xinjiang." Asian Affairs: An American Review 32 (2): 119-136. doi:10.3200/AAFS.32.2.119-136.

Simon, S. L., and A. Bouville. 2002. "Radiation Doses to Local Populations near Nuclear Weapons Test Sites Worldwide." Health Physics 82 (5): 706-725. doi:10.1097/00004032$200205000-00016$.

Sovacool, B. K., and S. V. Valentine. 2010. "The Socio-political Economy of Nuclear Energy in China and India." Energy 35 (9): 3803-3813. doi:10.1016/j.energy.2010.05.033.

Swanström, N. 2002. "China and Xinjiang after September 11." Nordic Institute for Asian Studies, 3.

Takada, J., 2008. "Dose Prediction for Surface Nuclear Explosions: Case Studies for Semipalatinsk and Lop Nur Test." IAEA, Accessed 9th Feb 2019. https://inis.iaea.org/ collection/NCLCollectionStore/_Public/41/092/41092730.pdf

Thacker, E. 2011. "Necrologies or the Death of the Body Politic." In Beyond Biopolitics, edited by Clough and Wilse, 139-162. Durham: Duke University Press.

Topping, S. 1964. "China Tests Atomic Bomb, Asks Summit Talk On Ban; Johnson Minimizes Peril." New York Times, October 17th, 1964. Retrieved 02 April 2019

Tursun, N. 2008, August. "The Formation of Modern Uyghur Historiography and Competing Perspectives toward Uyghur History." In China \& Eurasia Forum Quarterly 6: 3.

UN (United Nations). 1994. "Draft United Nations Declaration on the Rights of Indigenous Peoples Drafted by the Sub-Commission on Prevention of Discrimination and Protection of Minorities." Presented to the commission on human rights and the economic and social council at 36th meeting August 26, 1994. Accessed 5th Feb 2019.

UN (United Nations), "General Assembly." Document A/50/86, Feb 28, 1995 Accessed 5th Feb 2019. http://www.un.org/ga/search/view_doc.asp?symbol=A\%2F50\%2F86\&Submit= Search\&Lang $=\mathrm{E}$

UN (United Nations). 1995. "Statement on Security Assurances Issued on 5 April 1995 by the People's Republic of China." A/50/155 S/1995/265 English. Pp2. Accessed 5th Feb 2019.

UN (United Nations). 2019. Comprehensive Nuclear-Test-Ban Treaty (CTBT): History of the Treaty. Accessed 5th Feb 2019.

UNHRC (United Nations Human Rights Council). 2018. Summary of stakeholders' submissions on China*

OECD (Organisation for Economic Co-operation and Development). 2011. Uranium 2011: Resources, Production and Demand, "Red Book", OECD Nuclear Energy Agency and International Atomic Energy Agency (2012)

Wang, J. 2014. "On Area-specific Underground Research Laboratory for Geological Disposal of High-level Radioactive Waste in China." Journal of Rock Mechanics and Geotechnical Engineering 6 (2): 99-104. doi:10.1016/j.jrmge.2014.01.002.

WNA (World Nuclear Association). 2019. "China's Nuclear Fuel Cycle." World Nuclear Association, Accessed 03 February 2019.

Xu'ai, Y. (2014) Chinese Ethno-national Questions in the 20th Century (ershi Shiji De Zhongguo Minzu Wenti). by Wang Xi'en. Beijing: China Social Sciences Press, 2012, 726 pp.,¥ 118 (paperback), ISBN 9787516106174.

Yamamoto, M., M. Hoshi, J. Takada, A. Sakaguchi, K. N. Apsalikov, and B. I. Gusev. 2004. "Current Levels and Distribution of 137cs and Pu Isotopes in Soil on the Kazakhstan Territory of the Kazakhstan-Chinese Border: Semipalatinsk and Lop nor Nuclear Test Sites Detonation." Journal of Radioanalytical and Nuclear Chemistry 261 (3): 533-545. doi:10.1023/B:JRNC.0000037093.74415.7e. 
Zeeya, M., 2009. "Did China's Nuclear Tests Kill Thousands and Doom Future Generations?" Scientific American Magazine, July 8th, 2009. Accessed 9th Feb 2019.

Zenz, A. 2018. "'thoroughly Reforming Them Towards a Healthy Heart Attitude': China's Political Re-education Campaign in Xinjiang." Central Asian Survey (38) 1-27.

Zhang, H. 2017. "China's Fissile Material Production and Stockpile," International Panel on Fissile Material, December 2017, p. 2, 29-30. Accessed 5th February 2019 www.fissilematerials.org Zhang, H., and Y. Bai, 2015. "China's Access to Uranium Resources." Harvard Kennedy School, Belfer Center for Science and International Affairs. Accessed 9th Feb 2019.

Zhou, Y., C. Rengifo, P. Chen, and J. Hinze. 2011. "Is China Ready for Its Nuclear Expansion?" Energy Policy 39 (2): 771-781. doi:10.1016/j.enpol.2010.10.051.

Zhu, M. 1997. "The Evolution of China's Nuclear Nonproliferation Policy." The Nonproliferation Review 4 (2): 40-48. doi:10.1080/10736709708436664. 